\title{
Literature Review: Implementation of Posyandu Post-Covid-19 Pandemic Entering The New Normal
}

\author{
Shiva Nabilah \\ Faculty of Public Health, Muhammadiyah University of Jakarta \\ K.H. Ahmad Dahlan St, Cireundeu, Ciputat, South Jakarta, 15419 \\ E-mail: shivacipluk@gmail.com
}

\begin{abstract}
Posyandu is a form of community-based health effort that is managed and organized from, by, for, and with the community in implementing health development, to empower the community and provide convenience to the community in obtaining basic health services to accelerate the reduction of maternal and infant mortality. So far, the posyandu has a significant role in monitoring nutrition and children's health, since the COVID-19 pandemic the posyandu's role has been disrupted. Corona Virus Disease 2019 is a virus that was newly discovered in Wuhan, Hubei, China at the end of December 2019. This study aims to determine the description of the implementation of the posyandu after the COVID-19 pandemic entered the new normal period. The type of research literature review is a description of the theory, findings, and other research materials that are by the topic of discussion. The results of a literature review from 10 (ten) journals show that posyandu services have been carried out by paying attention to health protocols with facilities such as hand washing facilities/provision of Hand Sanitizer, body temperature measuring devices, Face Shield and PPE. The implementation of posyandu has complied with the Health Protocol following the technical instructions given by the ministry of health of the Republic of Indonesia. It is hoped that midwives, cadres, and the community in implementing the Posyandu after the COVID-19 pandemic enters the new normal period will continue to pay attention to health protocols.
\end{abstract}

Keywords: Implementation of Posyandu, Covid 19, and New Normal 


\section{INTRODUCTION}

Health is very important and can be used as one of the parameters to determine the quality of human resources (HR) of a country because the progress of a country can be seen from health services. In addition, health is an important factor for an individual, because a person's level of health also affects the individual's well-being.

Caring for the welfare of mothers and children from an early age is one of the strategies in implementing basic services, including improving the quality of nutrition and health, a healthy and safe environment, as well as creating psychosocial and emotional well-being, language skills, and cognitive abilities (thinking power and creativity). and protection of children from neglect. Posyandu is one of the integrated service posts for the community provided by the government, especially for mothers and babies so that they can carry out health checks every month to find out the healthy development of the mother and baby. Posyandu is a form of community-based health effort that is managed and organized from, by, for, and with the community in the implementation of health development, to empower the community and provide convenience to the community in obtaining basic health services to accelerate the reduction of maternal and infant mortality (Kemendagri). No. 19: 2011).

Programs, Strategies, and Guidelines for Community Empowerment in the Health Sector are contained in the Regulation of the Minister of Health Number 8 of 2019. The regulation of Community Empowerment contained in the Regulation of the Minister of Health Number 8 of 2019 concerning Community Empowerment in the Health Sector is used as a reference for the Central Government, Regional Governments, Institutions community, community organizations, the private sector, and other relevant stakeholders in realizing the active role and independence of the community for healthy living (Permenkes No. 8, 2019).

Based on the 2019 HDI ranking issued by the United Nations Development Program (UNDP) Index developed by Mahbub UI Haq in 1990, explaining that Indonesia in 2019 was ranked 111th out of 182 countries in 3 categories: Education, Health, and Income. A high ranking refers to the success of a country in developing and developing these three areas. In the health sector, one of the indicators of success is an infant and under-five mortality. In developed countries such as Australia, the infant and under-five mortality rate are 6 per 1000 births, the same figure is also owned by Malaysia. However, in Indonesia, the infant and under-five mortality rate are 41 per 1000 births. Thus, the HDI ranking in Indonesia is still far from that of other developed countries.

Posyandu has a general goal to support the acceleration of reducing maternal mortality (MMR), infant mortality (IMR), and under-five mortality rates (AKABA) in Indonesia by empowering the community. The posyandu target is the entire community, but the main targets are infants, children under five, pregnant women, postpartum and breastfeeding mothers, couples of 
E-ISSN: 2808-5361

http://e-journal.fkmumj.ac.id/
Proceeding The First Muhammadiyah InternasionalPublic Health and Medicine Conference

childbearing age (PUS). In 1986 Posyandu was launched with a total of 25,000 Posyandu, and in 2009 it increased to 266,827 Posyandu with a ratio of 3.55 Posyandu per village/kelurahan. However, when viewed from the quality aspect, there are still many problems, including the completeness of facilities and inadequate skills of cadres (Kemenkes RI, 2011).

Corona Virus Disease 2019 is a virus that was newly discovered in Wuhan, Hubei, China at the end of December 2019. This virus causes more serious diseases such as Pneumonia, Middle East Respiratory Syndrome (MERS-CoV), and Severe Acute Respiratory Syndrome (SARS-CoV). In March 2020, WHO declared Covid-19 a pandemic.

So far, the Posyandu has a significant role in monitoring nutrition and children's health, since the COVID-19 pandemic, the posyandu's role has been disrupted. The pandemic also disrupted immunization services, more than 50 percent of Posyandu and Puskesmas had completely stopped services due to this pandemic. Not a few parents have finally chosen to delay immunization because they are worried that doctors or workers other health who provide immunizations will be exposed to Covid-19, as well as health workers who are anxious if they have to serve patients during this pandemic (Tarigan and Ervina, 2020).

Of course, this condition cannot be allowed to continue, as the frontline health services for infants and toddlers, the Posyandu must begin to be active and be able to resume operations while still paying attention to the Covid-19 prevention health protocol so that they can continue to supervise and monitor the nutrition of infants and toddlers including immunization services Indonesian Ministry of Health, 2020b). Based on the analysis of the situation, there needs to be a literature review to find out the description of the implementation of the posyandu after the COVID-19 pandemic entered the new normal period.

\section{METHODS}

This research is a literature review study where it can be explained that a literature review is a description of theories, findings, and other research materials that are following the topic of discussion and obtained from reference materials that will be used as the basis for research activities. Search articles in research journal databases, search via the internet Google Scholar with the keywords implementation of posyandu, covid 19, and new normal. 10 articles were analyzed through analysis of objectives, suitability of topics, research methods used, sample size, results of each article, and limitations that occurred. The analysis was carried out to see things related to the implementation of the posyandu after the COVID-19 pandemic entered the new normal period. 


\section{RESULTS AND DISCUSSION}

Tabel 1. Article Review

\begin{tabular}{|c|c|c|c|c|}
\hline Researcher & Research Title & Research methods & $\begin{array}{c}\text { Respondents \& } \\
\text { Number of } \\
\text { Samples } \\
\end{array}$ & Research result \\
\hline $\begin{array}{l}\text { Amrina, Anggi } \\
\text { Fina. et al. } \\
(2020)\end{array}$ & \begin{tabular}{lr}
\multicolumn{2}{l}{ Pelaksanaan } \\
Kegiatan Posyandu \\
Pada rasa \\
Pandemi & Covid-19 \\
Sebagai & Upaya \\
Pemenuhan $r$ & Hak \\
Balita Dan Ibu & Hamil Sesuai \\
dengan & \\
Rekomendasi \\
Kementrian \\
Kesehatan \\
Republik Indonesia \\
di Desa Bongkok \\
Kecamatan Kramat \\
Kabupaten Tegal.
\end{tabular} & \begin{tabular}{lr}
\multicolumn{1}{c}{ This } & research \\
method & uses \\
qualitative methods \\
and interview and \\
observation \\
collection \\
techniques.
\end{tabular} & $\begin{array}{l}\text { Respondents of } \\
\text { this study } \\
\text { Respondents in } \\
\text { this study were } \\
\text { posyandu cadres, } \\
\text { medical } \\
\text { personnel, and } \\
\text { posyandu } \\
\text { members. }\end{array}$ & $\begin{array}{l}\text { The results of this } \\
\text { study show that the } \\
\text { implementation of the } \\
\text { posyandu that complies } \\
\text { with the Health } \\
\text { protocol has been } \\
\text { implemented at the } \\
\text { Posyandu in Bangkok } \\
\text { Village with facilities } \\
\text { including } \\
\text { handwashing } \\
\text { place/provision } \\
\text { Hand Sanitizer, body } \\
\text { temperature measuring } \\
\text { device, Face Shield } \\
\text { and PPE, but the lack } \\
\text { of awareness of } \\
\text { posyandu visitors } \\
\text { which is very difficult } \\
\text { to set the distance of } \\
\text { about } 1 \text { - } 1.5 \mathrm{~m} \text { from } \\
\text { each other and also } \\
\text { some who are not } \\
\text { wearing masks. }\end{array}$ \\
\hline $\begin{array}{l}\text { Juwita, D. R. } \\
(2020)\end{array}$ & $\begin{array}{lr}\text { Makna } & \text { Posyandu } \\
\text { Sebagai } & \text { Sarana } \\
\text { Pembelajaran Non } \\
\text { Formal Di Masa } \\
\text { Pandemic } \\
19 .\end{array}$ & $\begin{array}{l}\text { This research method } \\
\text { uses a Qualitative } \\
\text { Approach with Case } \\
\text { Study Research } \\
\text { Types. Data } \\
\text { collection techniques } \\
\text { were carried out } \\
\text { through } \\
\text { observation, } \\
\text { interviews, and } \\
\text { documentation. }\end{array}$ & $\begin{array}{l}\text { The subjects of } \\
\text { this study were } \\
\text { Posyandu cadres, } \\
\text { supervisory } \\
\text { officers from the } \\
\text { puskesmas, and } \\
\text { women in the } \\
\text { Mekar Sari } \\
\text { Posyandu area, } \\
\text { Kampung Baru } \\
\text { Palangka Raya. }\end{array}$ & $\begin{array}{l}\text { The results of the } \\
\text { study: } \\
\text { 1. Posyandu continues } \\
\text { to be held monthly } \\
\text { according to } \\
\text { schedule, during the } \\
\text { Covid-19 pandemic } \\
\text { era, posyandu cadres } \\
\text { and supervisors are } \\
\text { more creative in their } \\
\text { services because, } \\
\text { during the pandemic, } \\
\text { community } \\
\text { attendance } \\
\text { greatly decreased. } \\
\text { Therefore, creativity } \\
\text { in information } \\
\text { technology-based } \\
\text { services is needed so } \\
\text { that monitoring and } \\
\text { health services for } \\
\text { infants and toddlers } \\
\text { can continue to be } \\
\text { carried out. } \\
\text { 2. Posyandu as an Out- }\end{array}$ \\
\hline
\end{tabular}




Researcher Research Title $\quad$ Research methods $\begin{gathered}\text { Respondents \& } \\ \text { Number of } \\ \text { Samples }\end{gathered}$

Lindasari, Ni Pelaksanaan Pos This research method

Putu Ayu Pelayanan Terpadu is with observation to

(2020)

(Posyandu) Dan find out the problems
Sosialisasi Dalam that occur then carry

Upaya Pencegahan out prevention and

Covid-19 Pada Era control of the Covid

New Normal Di 19 virus.

Desa Gulingan respondent of this research is the

Head of Gulingan

Village and his

staff, Kelian

Dinas

Munggu,

Gulingan Village

Assistant

Midwife,

Posyandu Cadre in $\mathrm{Br}$. Munggu, along with the community of br.

Munggu.

\section{Research result}

of-school Education

Agency is interpreted as important for meeting the needs of Posyandu participants.

3. Posyandu as an outof-school education agency has been able to serve as an effective learning medium in the community, this is shown by understanding and enthusiasm and high awareness of public health services.
The results of this study are an increase in public understanding about the prevention of the covid 19 virus, an increase in public awareness when using masks out of the house, given how important health is and the public is starting to become aware of the dangers of covid-19.

\begin{tabular}{|c|c|c|c|c|}
\hline $\begin{array}{l}\text { Meilyana, E. et } \\
\text { al. }(2020)\end{array}$ & $\begin{array}{l}\text { Edukasi } \\
\text { Pemanfaatan } \\
\text { Pelayanan } \\
\text { Posyandu Pasca } \\
\text { Pandemik Covid- } \\
19 \text { Memasuki Masa } \\
\text { Newr Normal } \\
\text { Dalam Peningkatan } \\
\text { Kesehatan } \\
\text { Masyarakat. }\end{array}$ & $\begin{array}{l}\text { This research method } \\
\text { was carried out by } \\
\text { outreach using } \\
\text { leaflets, posters, and } \\
\text { direct education to } \\
\text { the community by } \\
\text { observing health } \\
\text { protocols. }\end{array}$ & $\begin{array}{l}\text { Conducted health } \\
\text { education to } \\
\text { health cadres and } \\
\text { the community } \\
\text { with a total of } 61 \\
\text { participants. }\end{array}$ & $\begin{array}{l}\text { Participants who } \\
\text { attended the activity } \\
\text { well to completion and } \\
\text { brought their children } \\
\text { for weighing, height } \\
\text { measurement, } \\
\text { examination, } \\
\text { immunization. } \\
\text { Participants } \\
\text { enthusiastic to ask } \\
\text { questions and wanted } \\
\text { to come to the } \\
\text { Posyandu with their } \\
\text { toddlers for health } \\
\text { monitoring and } \\
\text { immunization during } \\
\text { this new normal period } \\
\text { of COVID-19. }\end{array}$ \\
\hline
\end{tabular}




\begin{tabular}{|c|c|c|c|c|}
\hline Researcher & Research Title & Research methods & $\begin{array}{c}\text { Respondents \& } \\
\text { Number of } \\
\text { Samples }\end{array}$ & Research result \\
\hline $\begin{array}{l}\text { Purba, Anindya } \\
\text { Farinsa. et al. } \\
(2020)\end{array}$ & $\begin{array}{l}\text { Pendampingan } \\
\text { Pelaksanaan } \\
\text { Kegiatan Posyandu } \\
\text { ketika Pandemi } \\
\text { Covid-19 di } \\
\text { Posyandu Mawar V } \\
\text { Dusun Krajan Desa } \\
\text { Jetis }\end{array}$ & $\begin{array}{l}\text { This research method } \\
\text { uses a qualitative } \\
\text { approach and data } \\
\text { collection techniques } \\
\text { are carried out by } \\
\text { Observation, In- } \\
\text { Depth Interview, } \\
\text { Focus Group } \\
\text { Discussion, and } \\
\text { Documentation } \\
\text { Study. Data Analysis } \\
\text { Techniques Data } \\
\text { Reduction } \\
\text { Reduction), (Data } \\
\text { Conclusion Drawing } \\
\text { / Verification } \\
\text { (Withdrawal of } \\
\text { Conclusions } \\
\text { Verification). }\end{array}$ & $\begin{array}{l}\text { Respondents in } \\
\text { this study were } \\
\text { posyandu cadres } \\
\text { of Dusun Krajan, } \\
\text { members of } \\
\text { posyandu, and } \\
\text { PKK Lestari } \\
\text { cadres of Dusun } \\
\text { Krajan. }\end{array}$ & $\begin{array}{l}\text { In the implementation } \\
\text { of the posyandu at the } \\
\text { Mawar V Posyandu } \\
\text { Dusun Krajan The } \\
\text { implementation of the } \\
\text { posyandu during the } \\
\text { pandemic was carried } \\
\text { out following the } \\
\text { technical instructions } \\
\text { given by the ministry } \\
\text { of health of the } \\
\text { Republic of Indonesia. } \\
\text { Following the health } \\
\text { protocol rules } \\
\text { regarding the } \\
\text { implementation of } \\
\text { posyandu, posyandu } \\
\text { cadres and posyandu } \\
\text { participants } \\
\text { required to ure } \\
\text { personal protective } \\
\text { equipment such as } \\
\text { masks and or face } \\
\text { shields when } \\
\text { implementing } \\
\text { posyandu. }\end{array}$ \\
\hline $\begin{array}{l}\text { Ulfa, Rodia., \& } \\
\text { Syaiful (2020) }\end{array}$ & $\begin{array}{l}\text { Sosialisasi } \\
\text { Pembangunan } \\
\text { Fasilitas Posyandu } \\
\text { Sebagai Pendukung } \\
\text { Program Kesehatan } \\
\text { Anak Dimasa } \\
\text { Covid-19. }\end{array}$ & $\begin{array}{l}\text { This research method } \\
\text { is carried out using } \\
\text { an exploratory study } \\
\text { approach consisting } \\
\text { of literature studies, } \\
\text { field observations, } \\
\text { documentation, and } \\
\text { interviews. }\end{array}$ & $\begin{array}{l}\text { The respondents } \\
\text { of this research } \\
\text { are the people in } \\
\text { the neighborhood } \\
\text { where the } \\
\text { students live and } \\
\text { the program } \\
\text { chosen in } \\
\text { connection with } \\
\text { the Study } \\
\text { Program in this } \\
\text { case is Civil } \\
\text { Engineering. }\end{array}$ & $\begin{array}{l}\text { From this research, it } \\
\text { was found that: } \\
\text { 1. There is a need for } \\
\text { Posyandu facilities } \\
\text { that residents want, } \\
\text { 2. Factors are } \\
\text { supporting the } \\
\text { construction of } \\
\text { Posyandu facilities } \\
\text { 3. Generate } \\
\text { recommendations } \\
\text { for ideas that can } \\
\text { be given to } \\
\text { residents based on } \\
\text { existing factors. }\end{array}$ \\
\hline $\begin{array}{l}\text { Arsyati, Asri } \\
\text { Masitha. et al. } \\
(2020)\end{array}$ & $\begin{array}{ll}\text { Assessment } & \\
\text { Kesiapan } & \text { Kader } \\
\text { Posyandu } & \text { Dalam } \\
\text { Pelatihan } & \\
\text { Penggunaan } & \text { Media } \\
\text { Online. } & \end{array}$ & $\begin{array}{l}\text { This research method } \\
\text { is quantitative, with a } \\
\text { correlational design. }\end{array}$ & $\begin{array}{l}\text { Respondents of } \\
\text { this study were } \\
\text { Posyandu cadres } \\
\text { in RW 5 Cibadak } \\
\text { Village, Tanah } \\
\text { Sareal District, } \\
\text { Bogor City. }\end{array}$ & $\begin{array}{l}\text { The results of the study } \\
\text { concluded that as many } \\
\text { as } 73.8 \% \text { of cadres had } \\
\text { never attended online } \\
\text { training during the } \\
\text { pandemic. The attitude } \\
\text { of cadres towards the } \\
\text { holding of online } \\
\text { posyandu is positive, } \\
\text { as can be seen from the } \\
\text { willingness to } \\
\text { participate in } 89.5 \% \text {, } \\
\text { training can be done } \\
\text { online } 78.9 \% \text {. Most of }\end{array}$ \\
\hline
\end{tabular}




Researcher Research Title $\quad$ Research methods \begin{tabular}{c}
$\begin{array}{c}\text { Respondents \& } \\
\text { Number of } \\
\text { Samples }\end{array}$ \\
\hline
\end{tabular}
the cadres have used all the online meeting applications that were asked, namely $100 \%$ using WhatsApp video calls, $84 \%$ using zoom, $57.9 \%$ using Google Meet and google forms.

\begin{tabular}{|c|c|c|c|c|}
\hline \multirow{6}{*}{$\begin{array}{l}\text { Aritonang, } \\
\text { Juneris. et al. } \\
(2020)\end{array}$} & Kecemasan & This research method & The population in & The results of the study \\
\hline & $\begin{array}{l}\text { Pandemi Covid-19 } \\
\text { Dalam } \\
\text { Keikutsertaan }\end{array}$ & $\begin{array}{l}\text { uses a descriptive } \\
\text { research design and } \\
\text { data collection using }\end{array}$ & $\begin{array}{l}\text { this study were all } \\
\text { mothers who had } \\
\text { babies under five }\end{array}$ & $\begin{array}{l}\text { found that there was } \\
\text { high anxiety about the } \\
\text { Covid- } 19 \text { pandemic in }\end{array}$ \\
\hline & Posyandu & a questionnaire and & people & participation \\
\hline & Kelurahan & the data & using & Posyandu \\
\hline & Tanjung & analyzed & sampling. & Tanjung \\
\hline & Tahun 2020. & univariately. & & Village in 2020. \\
\hline
\end{tabular}

\begin{tabular}{|c|c|c|c|c|}
\hline $\begin{array}{l}\text { Jinan, RR, } \\
\text { Dewi, W., \& } \\
\text { Ainurrahmah } \\
(2021)\end{array}$ & $\begin{array}{lr}\text { Panduan } \\
\text { Pelaksanaan } \\
\text { Posyandu Di Masa } \\
\text { Pandemi Covid-19 } \\
\text { Pada Kader di } & \text { Rw } \\
05 \text { dan } 06 \\
\text { Kelurahan } \\
\text { Sukajaya } \\
\text { Kecamatan } \\
\text { Tarogong Kidul }\end{array}$ & $\begin{array}{l}\text { This research method } \\
\text { was carried out with } \\
\text { three activities, } \\
\text { namely socialization, } \\
\text { seminars on protocol } \\
\text { guidelines for the } \\
\text { implementation of } \\
\text { Posyandu, and } \\
\text { simulation of } \\
\text { Posyandu protocols } \\
\text { by measuring the } \\
\text { knowledge of cadres } \\
\text { before and after the } \\
\text { activity was carried } \\
\text { out to measure the } \\
\text { success of this } \\
\text { activity. Next, } \\
\text { distribute the results } \\
\text { of the training using } \\
\text { YouTube media. }\end{array}$ & $\begin{array}{l}\text { The respondents } \\
\text { of this study were } \\
\text { cadres in RW } 05 \\
\text { and 06, Sukajaya } \\
\text { Village, Tarogong } \\
\text { Kidul District, } \\
\text { Kab. Garut is } 18 \\
\text { participants. }\end{array}$ & $\begin{array}{l}\text { After the seminar and } \\
\text { the making of a video } \\
\text { on the Implementation } \\
\text { of Posyandu during the } \\
\text { Covid-19 Pandemic for } \\
\text { Cadre in Sukajaya } \\
\text { Village, Tarogong } \\
\text { Kidul District, Kab. } \\
\text { Garut posyandu cadres } \\
\text { better understand how } \\
\text { safe Posyandu } \\
\text { protocols are so that } \\
\text { Posyandu can still be } \\
\text { carried out safely even } \\
\text { during a pandemic and } \\
\text { it can be concluded } \\
\text { that there is a } \\
\text { significant increase in } \\
\text { knowledge and } \\
\text { understanding from } \\
\text { participants about the } \\
\text { implementation of } \\
\text { health protocols in the } \\
\text { implementation of the } \\
\text { Posyandu. }\end{array}$ \\
\hline $\begin{array}{l}\text { Rinata, Evi. et } \\
\text { al }(2021)\end{array}$ & $\begin{array}{l}\text { Posyandu Adaptasi } \\
\text { Kebiasaan Baru di } \\
\text { Desa Dukuhsari } \\
\text { Kecamatan Jabon } \\
\text { Sidoarjo. }\end{array}$ & $\begin{array}{l}\text { This research method } \\
\text { is Survey Partnership } \\
\text { Village, coordination } \\
\text { with PHC Jabon, } \\
\text { debriefing Kader \& } \\
\text { Socialization Covid- } \\
\text { 19, Provision of } \\
\text { Infrastructure } \\
\text { Support IHC } \\
\text { Adaptation New } \\
\text { Habits, Simulation }\end{array}$ & $\begin{array}{l}\text { Respondents are } \\
\text { volunteers and the } \\
\text { community. }\end{array}$ & $\begin{array}{l}\text { Cadres are enthusiastic } \\
\text { and participate in all } \\
\text { series of activities. The } \\
\text { Jabon Health Center is } \\
\text { also actively involved } \\
\text { in providing } \\
\text { reinforcements with } \\
\text { health promotion and } \\
\text { efforts to prevent the } \\
\text { transmission of Covid- } \\
19 .\end{array}$ \\
\hline
\end{tabular}




\begin{tabular}{lllll}
\hline Researcher & Research Title & Research methods & $\begin{array}{c}\text { Respondents \& } \\
\text { Number of } \\
\text { Samples }\end{array}$ & Research result \\
\hline & Procedure for IHC & \\
Adaptation New & \\
Habits, opening IHC & \\
Adaptation New & \\
Habits & \\
\hline
\end{tabular}

Based on the results of a literature review conducted in 10 journals and articles between 2020 and 2021 regarding the implementation of posyandu after the COVID-19 pandemic entered the new normal period. Research Purba, et al (2020) implementation of the posyandu at the Mawar V Posyandu Dusun Krajan The implementation of the posyandu during the pandemic was carried out by technical instructions given by the ministry of health of the Republic of Indonesia, as many as 20 posyandu participants consisting of mothers and children attended the posyandu activities. Participants who attended the posyandu by wearing masks or face shields, were orderly and aware of physical restrictions to prevent the covid-19 virus. In the implementation of the posyandu, participants consciously immediately wash their hands when they enter the posyandu implementation area in the space provided. Following Amina's research, et al (2020) from the results of observations and interviews, shows that the Posyandu conducted in Bangkok Village has complied with the Health Protocol according to the Technical Instructions for Immunization Services during the Covid-19 Pandemic recommended by the Ministry of Health of the Republic of Indonesia with facilities such as laundry facilities. hand/provision of Hand Sanitizer, body temperature measuring device, Face Shield, and PPE, but there is still a lack of awareness of posyandu visitors who are for a distance of about 1 $1.5 \mathrm{M}$ from each other and there are still some visitors who do not wear masks. So that there is a need for awareness from the public to be better in responding to the spread of the covid-19 virus, to increase public awareness of socialization and counseling about the dangers of covid-19. Following the research of Lindasari, et al (2020) after socialization about the dangers of covid-19 there was an increase in public understanding about the prevention of the covid-19 virus, there was an increase in public awareness when using masks out of the house, considering how important health is and people are starting to become aware of the dangers of covid-19. 19.

The covid-19 pandemic limits the space for movement in activities, but on the other hand, the implementation of posyandu is a must even in limited circumstances, the implementation of posyandu must use the correct health protocol procedures. Research by Aritonang, et al (2020) stated that the high anxiety of the COVID-19 pandemic in the participation of posyandu in Pekan Tanjung Morawa Village in 2020 resulted in low visits by mothers of toddlers during posyandu activities. The results of this study explain that the community is still not adapting to health service activities so it is necessary to innovate related to the creation of a safe posyandu during a pandemic following technical 
instructions, besides that it is necessary to do health promotion to increase knowledge, attitudes and change people's behavior. Posyandu movers are cadres from the community who voluntarily organize posyandu activities, but the knowledge and skills of cadres hinder the implementation of posyandu, therefore the training of posyandu cadres in carrying out their activities is an urgent need to be implemented immediately. Research Meilyana, et al (2020) conducted counseling to health cadres who served at the posyandu and mothers of toddlers in the Posyandu Mawar II area as many as 61 people with the application of health protocols, and for those who came regularly the counseling was still carried out by direct education to the community using leaflets, in addition to Health education is also carried out by visiting the homes of underprivileged residents as well as distributing necessities to improve family health. In line with the research of Jinan, et al (2020) By holding a seminar and making a video on the Implementation of the Posyandu Implementation Guide during the Covid-19 Pandemic for Cadres in Sukajaya Village, Tarogong Kidul District, Kab. In Garut, posyandu cadres better understand how the Posyandu protocol is safe so that Posyandu can still be carried out safely even during the pandemic.

During the Covid-19 pandemic, posyandu activities in the last few months have decreased due to having to comply with health protocols. According to research by Arsyati \& Chandra (2020) optimizing posyandu cadres by utilizing online media to organize posyandu online. Based on the characteristics of being able to scientifically understand technology, the majority of cadres are at the university level. The results of the study concluded that as many as $73.8 \%$ of cadres had never attended online training during the pandemic. The attitude of cadres towards the holding of online posyandu is positive, as can be seen from the willingness to participate in $89.5 \%$, training can be done online $78.9 \%$. Most of the cadres have used all the online meeting applications that were asked, namely $100 \%$ using WhatsApp video calls, $84 \%$ using zoom, 57.9\% using Google Meet and google forms. While the research was conducted by Rinata (2021) cadres were given the training to make a $0.5 \%$ chlorine solution disinfectant for decontamination and perform simulations as an illustration of the opening of the New Habit Posyandu, starting from coming to going home. Cadres demonstrate proper handwashing (CTPS), how to operate a digital baby scale. In addition, the cadres were also taught/simulated the use of a thermogenic to measure body temperature, simulated the recording of the $\mathrm{MCH}$ book, and the direction of the service team regarding the circulation of Posyandu services to all cadres.

\section{CONCLUSION AND SUGGESTIONS}

Based on the results of an analysis of 10 journals that have been conducted by the author regarding the implementation of the posyandu after the covid-19 pandemic entered the new normal period, the researchers hereby conclude that the implementation of the posyandu has complied with the Health Protocol following the technical instructions 
given by the Ministry of Health of the Republic of Indonesia, with facilities such as handwashing places or the provision of Hand Sanitizers, body temperature measuring devices, Face Shields, and PPE

It is hoped that midwives, cadres, and the community in implementing the Posyandu after the COVID-19 pandemic enters the new normal period will continue to pay attention to health protocols. Suggestions that can be given for further research in the implementation of a literature review are to use more databases and use the latest articles and journals.

\section{REFERENCES}

Amrina, A. F. dkk. (2020). Pelaksanaan Kegiatan Posyandu Pada Masa Pandemi Covid-19 Sebagai Upaya Pemenuhan Hak Balita Dan Ibu Hamil Sesuai Dengan Rekomendasi Kementerian Kesehatan Republik Indonesia Di Desa Bongkok Kecamatan Kramat Kabupaten Tegal. Journal of Chemical Information and Modeling.

Aritonang, J. dkk. (2020). Kecemasan Pandemi Covid-19 Dalam Keikutsertaan Posyandu Di Kelurahan Pekan Tanjung Morawa Tahun 2020. Jurnal Reproductive Health, 6(1), hal. 3442.

Arsyati, A. M. dan Chandra, V. K. (2020). Assessment Kesiapan Kader Posyandu dalam Pelatihan Penggunaan Media Online. Hearty Jurnal Kesehatan Masyarakat, 8(1), hal. 27-32. Tersedia pada: http://ejournal.uika-bogor.ac.id/index.php/Hearty/article/download/3635/2019.

Kementerian Kesehatan RI. (2011). Pedoman Umum Pengelolaan posyandu. Jakarta: Kementerian Kesehatan RI.

Kementerian Kesehatan RI (2020b) Petunjuk Teknis Pelayanan Imunisasi Pada Masa Pandemi Covid19.

Lindasari, N. P. A. dkk. (2020). Pelaksanaan Pos Pelayanan Terpadu (Posyandu) Dan Sosialisasi Dalam Upaya Pencegahan Covid-19 Pada Era New Normal Di Desa Gulingan.”

Meilyana, E. dkk. (2020). Edukasi Pemanfaatan Pelayanan Posyandu Pasca Pandemik Covid-19 Memasuki Masa New Normal Dalam Peningkatan Kesehatan Masyarakat, Jurnal Ilmiah Pengabdian Kepada Masyarakat, 4(2), hal. 604-610.

Jinan, R. R. dkk. (2021). Panduan Pelaksanaan Posyandu Di Masa Pandemi Covid-19 Pada Kader Di Rw 05 Dan 06 Kelurahan Sukajaya Kecamatan Tarogong Kidul Kab. Garut. Abdimas Siliwangi, 04(01), Hal. 115-120. Doi: Xx.Xxxxx/Abdimas-Siliwangi.Xxxx.Xxxxx.

Peraturan Menteri Kesehatan No.8 Tahun 2019, Pemberdayaan Masyarakat Bidang Kesehatan, KEMENKES RI, Jakarta.

Purba, A. F. dkk . (2005). Pendampingan Pelaksanaan Kegiatan Posyandu ketika Pandemi Covid-19 di Posyandu Mawar V Dusun Krajan Desa Jetis. 
Rinata, E. dkk. (2021) "Posyandu adaptasi kebiasaan baru di desa dukuhsari kecamatan jabon sidoarjo," Journal of Service Learning, 7(1), hal. 32-37. doi: 10.9744/share.7.1.32-37.

Tarigan, M. and Ervina, S. (2020) 'Alarm Imunisasi di Kala Pandemi', Tempo.co. Available at: https://interaktif.tempo.co/proyek/imunisasi- saat-coronavirus/index.html.

Ulfa, R. Dan Syaiful (2020) "Sosialisasi Pembangunan Fasilitas Posyandu Sebagai Pendukung Program Kesehatan Anak Dimasa Covid-19," Program Mahasiswa Kreatif, 4(2). Doi: Https://Doi.Org/10.32832/Pkm-P.V4i2.752.

Juwita, D. R. (2020). Makna Posyandu Sebagai Sarana Pembelajaran Non Formal Di Masa Pandemic Covid 19. Meretas: Jurnal Ilmu Pendidikan, 7(1), hal. 1-15. 
Volume I Tahun 2021

November 2021
E-ISSN: 2808-5361

http://e-journal.fkmumj.ac.id/
Proceeding The First Muhammadiyah InternasionalPublic Health and Medicine Conference 